\title{
PROFIT ANALYSIS OF VARIOUS GARLIC CULTIVATION INPUT PACKAGES AFFECTED BY WATER STRESS IN RAINFED HIGHLANDS OF EASTERN LOMBOK, INDONESIA
}

\author{
Utami Sylvia Kusumaputri, Mardiana, Herawati Nani, Sugianti Titin, \\ Matenggomena Muhammad Faesal, Darwis, Hidayah Baiq Nurul* \\ Indonesian Agency for Agricultural Research and Development (IAARD) - \\ Institute for Assessment of Agricultural Technology (Balai Pengkajian Teknologi Pertanian), \\ West Nusa Tenggara Province, Indonesia \\ *E-mail: baiqnurul@pertanian.go.id
}

\begin{abstract}
Agricultural production influenced by several factors including climate change such as drought. Agriculture is vulnerable sector to drought because it influences cropping patterns, planting time, cropping index, production, yield quality, and profit. This study aims to investigate the profitability of garlic cultivation influenced by water stress at various input packages in the rainfed highlands of Eastern Lombok, Indonesia (1200 m above sea level). Input packages that applied were reducing use of chemical fertilizers and pesticides up to $50 \%$ from farmers' practices. Applied input consists of 4 packages, namely P1 (farmers' existing practices), P2, P3 and P4 as reduced and modified input packages. Field experiment was conducted in Sembalun Highlands from February to June 2018 on a 0.4 ha rainfed highlands using randomized completely block design followed by economic analysis. Parameters observed were Revenue/Cost $(\mathrm{R} / \mathrm{C})$ ratio based on fresh and dry weight yield. Results show that highest $R / C$ ratios for fresh yield was from farmers' existing treatment (P1) followed by P4 with the value of 1.33 and 1.28 respectively, whilst for dry yield were 1.39 and 1.36 respectively, which means that expenditure of IDR 1 will generate revenue of IDR 1.33 and 1.28 for fresh garlic bulb, while for dry garlic buld were 1.39 and 1.36 respectively. However, in term of soil sustainability issue, treatment P4 is expected to be applied. This figure decreases when compared to the production of garlic in normal conditions. Drought that occurred since early April caused the crop faced water stress and unable to provide an optimal agronomic performance and productivity which led to decreasing yield and profitability for about $40-50 \%$.
\end{abstract}

\section{KEY WORDS}

Cost, drought, garlic, profitability, revenue.

In conducting farming activities, it is important to determine the value of economic, social, and financial viabilities. Economic feasibility shows the overall regional economy of a land use system for the community, therefore it can be seen the efficiency of land resource utilization. Whereas social feasibility is seen from the distribution of costs and benefits between stakeholders, and financial feasibility, to find out whether the farming carried out is feasible or not to be attempted. If feasible, then the farming can be continued and developed, it is expected to have a positive impact in the form of benefits to be received, such as an increase in income from the perpetrators of the farming. Whereas if it is not feasible to be endeavored, then there are alternatives in the form of actions, such as stoppage or improvement, and the form of improvement itself can be in the form of conservation or diversification, and intensification (Sulistyanto, 2013).

Agricultural development requires technological innovation that is always developing. Utilization of agricultural technological innovations is intended to increase agricultural productivity through the optimization of existing technologies or by developing technological innovations. At the level of the concept of innovation, the technology created needs to consider the needs of users and the supporting factors so that technological innovation can be adopted quickly and accurately. Facts on the ground show that the adoption of agricultural 
technology innovations at the farm level is still relatively low so that agricultural productivity achieved is not in accordance with the existing potential. This is due to the diversity of farmers' perceptions and responses to technological innovations (Indraningsih, 2015).

Indonesian Statistical Bureau revealed that from 2001 to 2010 the annual consumption of garlic for the industry was less than 5 percent. This shows that the biggest consumption is from the household sector. This large consumption is not matched by the large domestic availability therefore import activities cannot be avoided. Indonesia continued to import garlic until FAO named Indonesia as the largest importer of garlic (Wijaya, 2014). National garlic needs are estimated at 500,000 tons per year, only able to be met by domestic production of 20,000 tons, or about $4 \%$. West Nusa Tenggara (WNT) Province is the biggest garlic producer in Indonesia, where $48 \%$ of total local garlic production in Indonesia is produced in WNT Province (Centre of Statistical Bureau, 2016).

One reason a business can be carried out is if the business is financially feasible. To be able to measure the feasibility of an input-saving garlic technology packages, it is necessary to identify the technology package, financial analysis, and the feasibility of the farm. In addition, the social aspects of the community in accepting technology and how the development strategy also needs to be assessed therefore the business can be sustainable. The purpose of this study was to determine the feasibility garlic input-saving cultivation packages in Sembalun Highlands of Eastern Lombok when influence by water stress.

\section{MATERIALS AND METHODS OF RESEARCH}

The experimental site was a farmer's field with horticulture commodities cropping patterns; soil $\mathrm{pH}$ was around 5.5 with sandy sand structure. The location is a horticultural area during the rainy season, and includes in a category of rainfed highlands. The irrigation process relies on rainfall. The soil condition at the sowing time was suitable for planting garlic, but when the plants grow up to harvest there is no rain, therefore the plants experienced water stress. The location of the experimental site is shown in Figure 1.

A field experiment was conducted in the Sembalun Higlands (1200 m asl) in Eastern Lombok of Indonesia from February to June 2018 to investigate cultivation input packages on agronomic performance and yield of a local variety of garlic followed by profit analysis. The experimental design was a completely randomized block of four blocks. Each block consisted of four treatments: 1) Farmers' usual cultivation input package (P1); 2) Cultivation Input Package I (P2); 3) Cultivation Input Package II (P3); and 4) Cultivation Input Package III (P4). Therefore, there were sixteen plots in total. The experimental was 0.4 ha comprising four replication blocks of 0.1 ha each. The details of the cultivation input package are shown in Table 1.

In accordance with the objectives to investigate the profitability of the farming activities, the approach used was an explanatory survey method (Singarimbun and Effendy, 1995). To give meaning to the variables collected through the survey method, the data from the variables are collected in the following ways: (1) Observation, which is a data collection technique by observing the symptoms of the subjects being investigated, both the observation is carried out in actual situations and in specific artificial situations held through action studies. (2) In-depth interviews, namely data collection techniques by interviewing respondents using a structured questionnaire. While in-depth interviews with informants about objects or various things that are being investigated by using the guidelines/points of semi-structural interviews (Muhajir, 2000; Mulyana, 2001). (3) Participation observation, which is a data collection technique by directly observing the symptoms of the subjects being investigated in the actual situation (Muhajir, 2000; Mulyana, 2001). (4) In the observation of involvement, a focus group discussion was conducted.

The stages of this activity include starting with identifying the location of field experiment conducted by IAAT WNT Province. Then determined the location and prospective respondent farmers in accordance with the criteria needed. After that, in-depth interviews with respondent farmers (cooperators and non-cooperators) using questionnaires that have been prepared. This questionnaire was intended to obtain data on social and 
economic aspects. The completed questionnaire was then entered with the raw data and then processed using the available analysis tools.

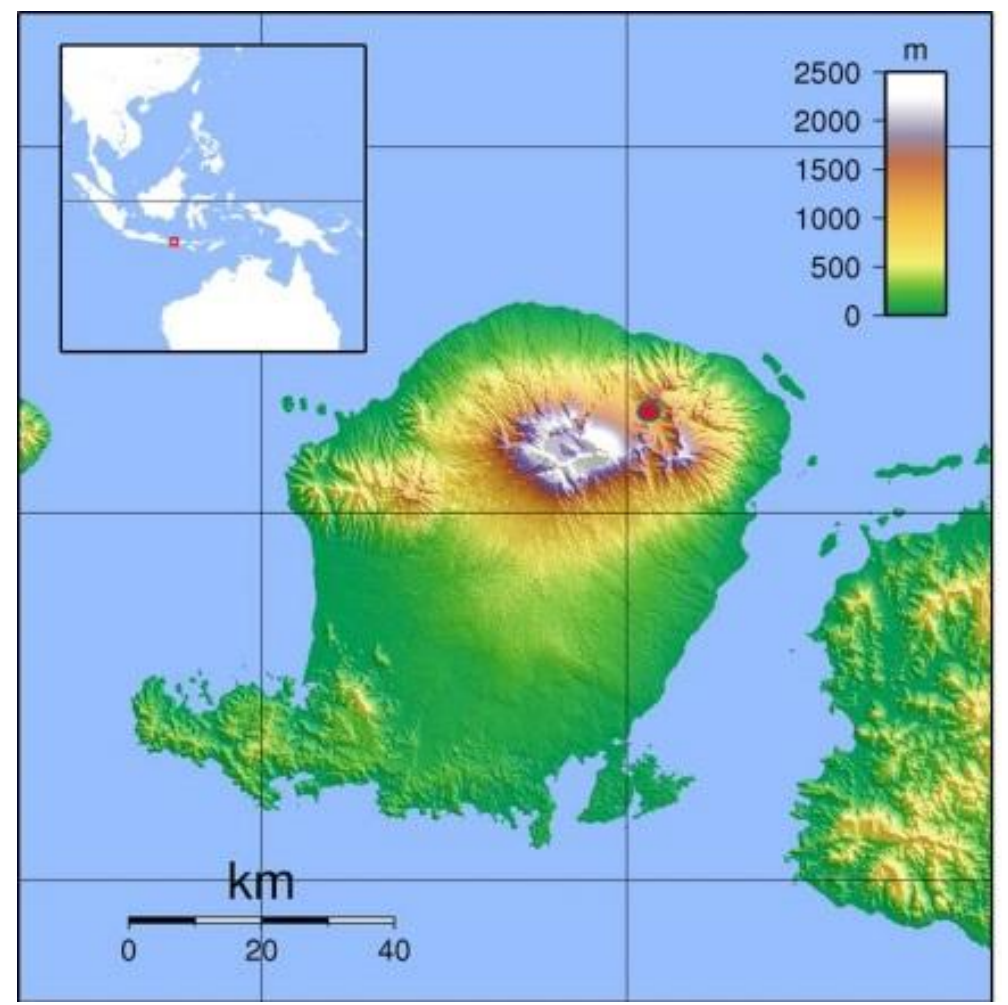

Figure 1 - Map of Lombok Island where the experimental site is in Sembalun highlands of Eastern Lombok with red dot sign on the upper right part of the island

Table 1 - Cultivation input packages applied in field experiment during the growing season of 2018

\begin{tabular}{lllll}
\hline \multirow{2}{*}{ Inputs } & Existing Input Package & \multicolumn{2}{l}{ Modified Cultivation Input Packages } & \\
\cline { 3 - 5 } & $(\mathrm{P} 1)$ & $(\mathrm{P} 2)$ & $(\mathrm{P} 3)$ & $(\mathrm{P} 4)$ \\
\hline Dolomite $(\mathrm{kg} / \mathrm{ha})$ & 0 & 1000 & 750 & 500 \\
Cow manure $(\mathrm{kg} / \mathrm{ha})$ & 3,000 & 10,000 & 7,500 & 5,000 \\
$\mathrm{NPK} \mathrm{16:16:16}(\mathrm{kg} / \mathrm{ha})$ & 500 & 400 & 300 & 200 \\
$\mathrm{SP}-36(\mathrm{~kg} / \mathrm{ha})$ & 400 & 300 & 250 & 200 \\
$\mathrm{ZA}(\mathrm{kg} / \mathrm{ha})$ & 400 & 300 & 250 & 200 \\
$\mathrm{KCl}(\mathrm{kg} / \mathrm{ha})$ & 300 & 250 & 200 & 150 \\
Pest control & Existing technology & Spraying pesticides & Spraying & Spraying \\
& (mixing pesticides as & based on rotation & pesticides based & pesticides based \\
& usual used by farmers) & strategies & on rotation & on rotation \\
& & & strategies & strategies \\
\hline
\end{tabular}

The types of data collected in this study include primary and secondary data. Primary data was collected through Focus Group Discussion (FGD), interviews using questionnaires, and direct observation. Secondary data was collected with desk study taken from the library or related department. Respondents in this activity were selected by purposive sampling where the selection of respondents was based on predetermined criteria.

To answer the objectives, the data collected was analyzed using qualitative analysis and feasibility analysis (Revenue/Cost Ratio) methods. The location determination technique is conducted by using purposive sampling where the location is taken based on certain considerations, namely the location of the field experiment by IAAT WNT Province.

\section{RESULTS AND DISCUSSION}

Existing condition of garlic farmers in Sembalun Highlands. Economically, garlic farmers generally need high capital to be able to grow garlic. Farmers continue to exploit the land by using chemical fertilizers and pesticides that do not follow the recommendations. In 
the assessment of garlic, 4 treatments were carried out to see how the effect of regulating fertilizer dosages on garlic crops. The use of organic fertilizer is also included in this treatment. In general, farmers are aware that the soil in Sembalun Highlands needs organic fertilizer to restore soil nutrients that have begun to feed and cause low crop production. However, the use of organic fertilizer such as compost/manure is still difficult because it requires a very large amount while in general cattle that produce manure to be composted are not caged so that the manure is not collected. Besides that, the process which is gradual and not immediately visible also makes farmers prefer chemical fertilizers that are easier to obtain.

Environmental constraints. The experimental site was a farmers' field with horticulture commodity cropping patterns; the sandy sand soil had a $\mathrm{pH}$ of 5.5. The location is a rainy season horticultural area in East Lombok Regency, categorised as a rainfed highlands. The crop's water needs relied on rainfall. Soil moisture at sowing was suitable for planting garlic, but as the crop matured and approached harvest there was no rain resulting in water stress. Soil analysis at the IAAT laboratory was sandy sand where sand was more dominant than dust and clay. The $\mathrm{pH}$ below 6 was ideal site for treatment of dolomite for increasing $\mathrm{pH}$ in order to make the soil more productive (Rochayati et al., 1986).

This 2018 field experiment was affected by a lack of rain from the beginning of April when the crops were 45 days old and begining bulb formation. Treatments which were planted from the 17-18 February received sufficient rainfall during early vegetative growth, but from early April rainfall in the Sembalun highlands was far below average which meant the crops were water stressed during the period when they needed water most. Water deficit seriously threatens crop productivity worldwide (Sánchez-Virosta and Sánchez-Gómez, 2019). Rainfall data for the Sembalun highlands during the growth of the field experiment can be seen in Figures 2 and 3.

Figure 2 shows the comparison of rainfall in 2017 and 2018. In April 2018 the rainfall deficit was $153 \mathrm{~mm}$ compared to April 2017 which had rainfall of $154 \mathrm{~mm}$. Likewise; in May 2018 there was no rain at the experimental site, whilst $11 \mathrm{~mm}$ of rain fell in the same month of the previous year. The 2018 rainfall is an anomaly because in previous years from April and May there has been sufficient rain for crops in the rainfed areas in Sembalun highlands according cooperating farmers.

Figure 3 shows the comparison of rainy days in the Sembalun highlands during the field experiment sown from 17-18 February 2018. The number of rainy days during the vegetative growth period, i.e from February to March 2018, shows enough rainy days (even relatively excessive). However, from the beginning of April the dry season occured early, therefore the number of rainy days when the crops still needed water was very limited. In 2017 April and May had 14 and 3 rainy days respectively, while in 2018 April and May had only 2 and 1 rainy day respectively. The water deficit happened when the garlic treatments had started bulb formation and required plentiful water. Water is very important to obtain maximum yield especially during bulb formation (Sadaria et al., 1997). Bulbs tend to have reduced size if water stress occurs during bulb formation (Fabeiro Cortes et al., 2003). Furthermore, Nam et al. (2007) stated that water stress influences both agronomic growth and bulb size.

In addition, there was an increase in temperature, especially in March and April 2018 compared to the same month in 2017. In April 2018, the maximum temperature was $27.6^{\circ} \mathrm{C}$ while in the same month of the previous year was only $27.1^{\circ} \mathrm{C}$ (Figure 4). The maximum temperature in April 2018 reached $27.6^{\circ} \mathrm{C}$ while in the same month of the previous year it was hald a degree lower at $27.1^{\circ} \mathrm{C}$. We also felt this temperature increase when we were in the field due to the wind accompanied by heat waves which also affected the speed of the crops were dry out as an additional result after the absence of rainfall. However, there were no data that indicated the level of wind speed accompanied by heat waves due to the unavailability of tools in the field to measure the data. Anonymous (1998) stated that garlic crops adaptive in temperature between $15-20^{\circ} \mathrm{C}$. If the temperature is below $15^{\circ} \mathrm{C}$, the crop growth is disrupted and slow, while if the temperature is above $27^{\circ} \mathrm{C}$ bulb formation is also disrupted. 
Growth performances of garlic crops affected by water stress during the field experiment are shown in Figure $5-8$. The crops severe affected by water stress since 45 days after sowing when the bulb formation started until harvest. Early harvest was conducted when the crops at 90 days after sowing, this is $10-20$ days earlier since this variety normally harvested at 100-110 days after sowing.

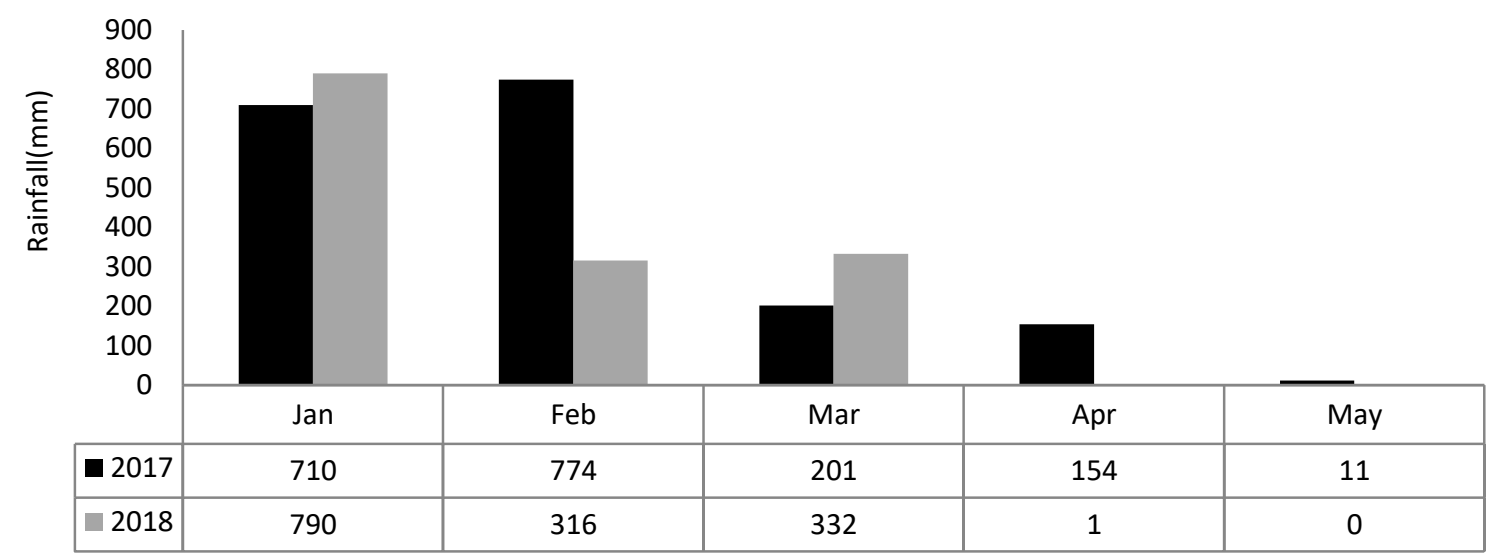

Figure 2 - Rainfall in the Sembalun highlands during the field experiment of input-saving garlic cultivation in growing season of 2018



Figure 3 - Number of rainy days in the Sembalun highlands during the field experiment in the growing season of 2018

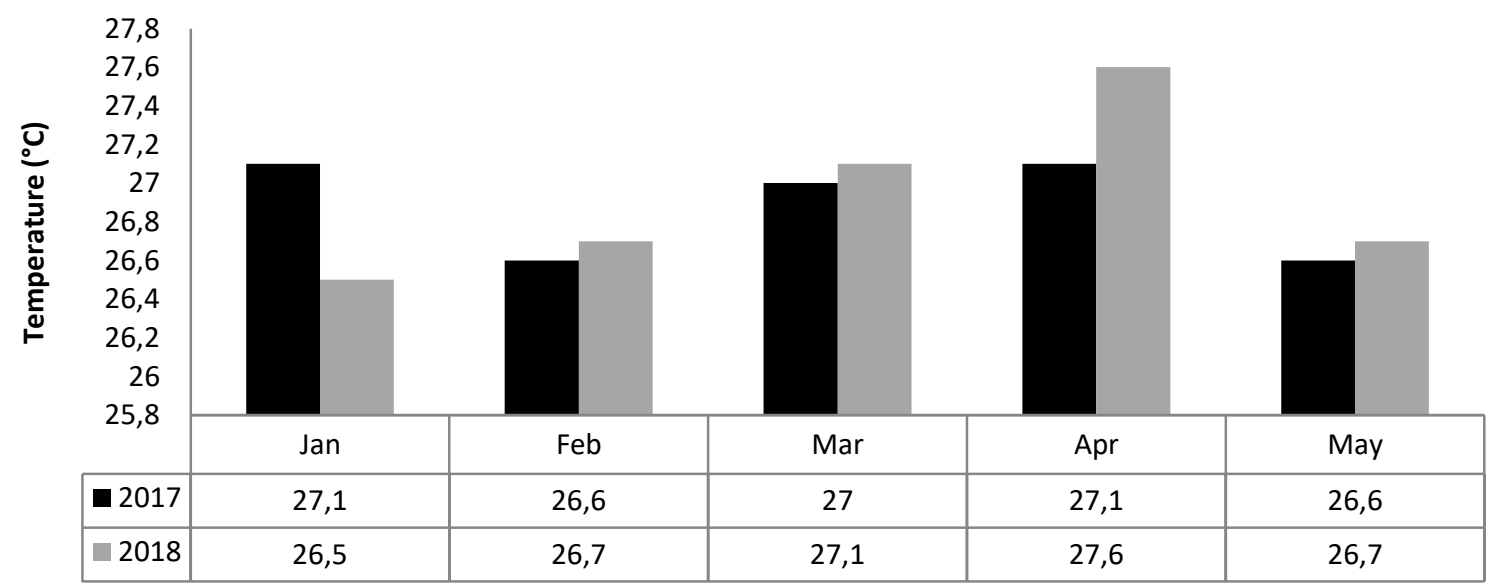

Figure 4 - Air temperature in the Sembalun highlands during the field experiment in growing season of 2018 




Figure 5 - Growth performace of garlic crops at 30 days after sowing



Figure 7 - Growth performance of garlic crops at 82 days after sowing affected by water stress

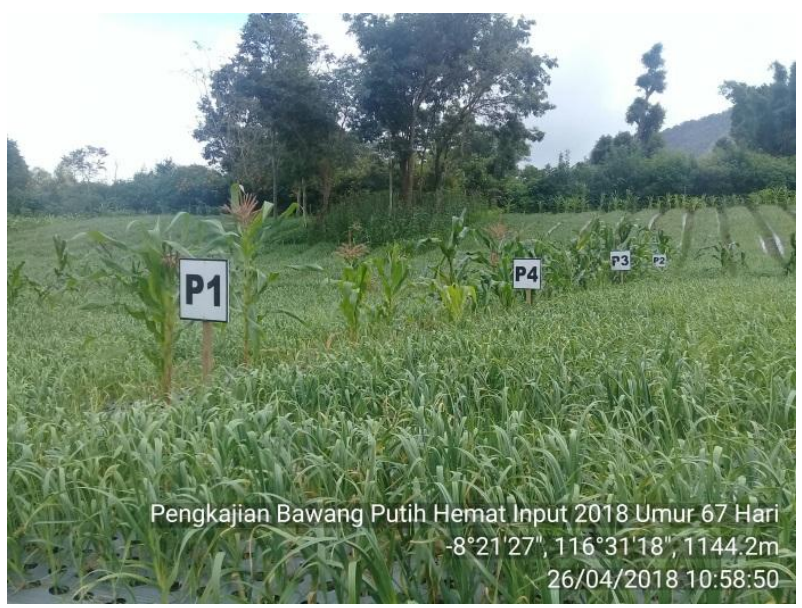

Figure 6 - Growth performance of garlic crops at 67 days after sowing

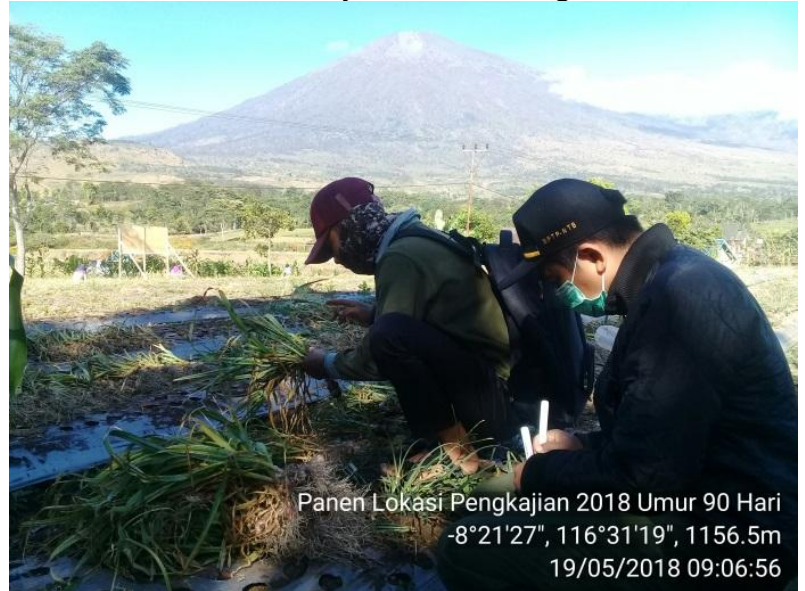

Figure 8 - Earlier harvested of garlic crops at 90 days after sowing due to water stress

Revenue/Cost Analysis. The high use of inputs for garlic cultivation in Sembalun Highlands have been applied on for generations. This condition if it continues will worsen the condition of the soil in the region if it is not accompanied by the use of organic fertilizer to minimize the use of excessive chemical fertilizer. Table 2 shows that the highest cost is treatment P2, which was IDR 14,533,000. The highest cost is the cost of seeds and labor. The difference in cost between each treatment lies in the cost of using fertilizer because it differs between treatments. In P2, the cost of manure is the biggest cost of using fertilizer compared to other treatments. This is due to the use of manure which is expected to increase the productivity of garlic. while the lowest cost is in treatment P4, where all doses of fertilizer use were minimized for cost savings.

Garlic production among 4 treatments turned out to have a difference that is not much different. The highest yield was obtained from farmers' existing technology, which was 1,254 $\mathrm{kg}$ per treatment for the results of fresh garlic $(0.1 \mathrm{ha})$ and $489.2 \mathrm{~g}$ per dry weight per treatment $(0.1 \mathrm{ha})$. Among those four treatments, the highest $\mathrm{R} / \mathrm{C}$ ratios for fresh yield was from farmers' existing treatment (P1) followed by the least inputs cultivation package (P4) with the value of 1.33 and 1.28 respectively, whilst for the dry yield were 1.39 and 1.36 respectively. This is means that expenditure of IDR 1 will generate revenue of IDR 1.33 and 1.28 for fresh garlic bulb, while for dry garlic bulb were 1.39 and 1.36 respectively (Table 3 and 4). However, in term of soil sustainability issue in the region, treatment P4 is expected to be applied since applied organic fertilizer with wise use of pesticides. These figures decreased when compared to the yield of garlic in normal conditions. Drought that occurred since early April caused the crop faced water stress and unable to provide an optimal 
agronomic performance and productivity which led to decreasing yield and profitability for about $40-50 \%$.

Table 2 - Financial analysis of garlic cultivation per treatment

\begin{tabular}{|c|c|c|c|c|}
\hline \multirow{2}{*}{ Inputs } & \multirow{2}{*}{$\begin{array}{l}\text { Farmers' existing practices (P1) } \\
\text { (IDR) }\end{array}$} & \multicolumn{3}{|c|}{ Input Package (IDR) } \\
\hline & & $\mathrm{P} 2$ & P3 & P4 \\
\hline \multicolumn{5}{|l|}{ Inputs cost } \\
\hline Seed & $6,000,000$ & $6,000,000$ & $6,000,000$ & $6,000,000$ \\
\hline Seed & $6,000,000$ & $6,000,000$ & $6,000,000$ & $6,000,000$ \\
\hline Fertilizers & 613,000 & $1,033,000$ & 569,750 & 306,500 \\
\hline Dolomite & 100,000 & 200,000 & 100,000 & 50,000 \\
\hline Manure & 240,000 & 600,000 & 300,000 & 150,000 \\
\hline NPK Phonska & 92,000 & 69,000 & 46,000 & 23,000 \\
\hline SP-36 & 60,000 & 50,000 & 40,000 & 30,000 \\
\hline $\mathrm{ZA}$ & 28,000 & 21,000 & 14,000 & 7,000 \\
\hline Urea & 18,000 & 18,000 & 13,500 & 9,000 \\
\hline $\mathrm{KCl}$ & 75,000 & 75,000 & 56,250 & 37,500 \\
\hline Pesticides & $1,500,000$ & $1,500,000$ & $1,500,000$ & $1,500,000$ \\
\hline Labors & $6,000,000$ & $6,000,000$ & $6,000,000$ & $6,000,000$ \\
\hline Total & $14,113,000$ & $14,533,000$ & $14,069,750$ & $13,806,500$ \\
\hline
\end{tabular}

Table 3 - Profit analysis of fresh garlic yield per treatment

\begin{tabular}{llllll}
\hline \multirow{2}{*}{ No } & Profit Analysis & \multirow{2}{*}{ Farmers' Existing Practices (P1) } & \multicolumn{2}{l}{ Input Package } & \\
\cline { 4 - 6 } & & & P2 & P3 & P4 \\
\hline 1 & Fresh yield (kg) & 1,254 & 1,094 & 1,099 & 1,178 \\
2 & Price (IDR) & 15,000 & 15,000 & 15,000 & 15,000 \\
3 & Income (IDR) & $18,809,809$ & $16,412,480$ & $16,486,244$ & $17,666,467$ \\
4 & Production cost (IDR) & $14,113,000$ & $14,533,000$ & $14,069,750$ & $13,806,500$ \\
5 & Profit (IDR) & $4,696,809$ & $1,879,480$ & $2,416,494$ & $3,859,967$ \\
\hline & R/C ratio & 1.33 & 1.13 & 1.17 & 1.28 \\
\hline
\end{tabular}

Table 4 - Profit analysis of dry garlic yield (after drying for one month) per treatment

\begin{tabular}{llllll}
\hline \multirow{2}{*}{ No } & Profit Analysis & Farmers' existing practices (P1) & \multicolumn{3}{l}{ Input Package } \\
\cline { 3 - 5 } & & & P2 & P3 & P4 \\
\hline 1 & Dry yield (kg) & 489.2 & 444.7 & 447.7 & 468.4 \\
2 & Price (IDR) & 40,000 & 40,000 & 40,000 & 40,000 \\
3 & Income (IDR) & $19,567,308$ & $17,788,462$ & $17,907,051$ & $18,737,179$ \\
4 & Production cost (IDR) & $14,113,000$ & $14,533,000$ & $14,069,750$ & $13,806,500$ \\
5 & Profit (IDR) & $5,454,308$ & $3,255,462$ & $3,837,301$ & $4,930,679$ \\
\hline & R/C ratio & 1.39 & 1.22 & 1.27 & 1.36 \\
\hline
\end{tabular}

\section{CONCLUSION}

Based on the results of this study, it was known highest $\mathrm{R} / \mathrm{C}$ ratios for fresh yield was from farmers' existing treatment (P1) followed by the least inputs cultivation package (P4) with the value of 1.33 and 1.28 respectively, whilst for dry yield were 1.39 and 1.36 respectively. This is means that expenditure of IDR 1 will generate revenue of IDR 1.33 and 1.28 for fresh garlic bulb, while for dry garlic bulb were 1.39 and 1.36 respectively. However, in term of soil sustainability issue, treatment P4 is expected to be applied. These figures decreased when compared to the yield of garlic in normal conditions. Drought that occurred since early April caused the crop faced water stress and unable to provide an optimal agronomic performance and productivity which led to decreasing yield and profitability for about $40-50 \%$.

\section{CONFLICT OF INTERESTS}

Authors clearly declare that they have no competing interests.

\section{ACKNOWLEDGEMENTS}

These findings were based on the project entitled "Low input cultivation packages on garlic in West Nusa Tenggara Province of Indonesia" through the 2018 annual budget of the 
Institute for Assessment of Agricultural Technology (IAAT), West Nusa Tenggara Province, Indonesia. The first author was the main contributor of this paper, while the second to the seventh authors were the supporting contributors. We thanks Dr. Ir. M. Saleh Mokhtar, MP., director of IAAT West Nusa Tenggara Province for his support for the garlic team in implementation of the garlic research project in 2018. We thanks Lalu Onang, Dedi Iskandar, and Ayu Lestari Sania for their technical assistance in the field.

\section{REFERENCES}

1. Arsyad, S. (2006). Soil and Water Conservation. IPB University Press, Bogor, Indonesia. (in Indonesian).

2. Centre of Statistical Bureau. (2016). Indonesia in Figures. Centre of Statistical Bureau, Republic of Indonesia, Jakarta. (in Indonesian).

3. Fabeiro Cortés, C., Martín de Santa Olalla, F., López Urrea, R. (2003). Production of garlic (Allium sativum L.) under controlled deficit irrigation in a semi-arid climate. Agric. Water Manage. 59: 155-167.

4. Firmansyah, Apriani H., Dianita R. (2016). The Feasibility of the Integration Model of Sugarcane Farming with Cattle Farming in Supporting the Welfare of Farmers in Kerinci Regency. Journal of Animal Sciences Vol 19, No. 1: 46-54. (in Indonesian).

5. Gittinger, J.P. (1986). Economic Analysis of Agricultural Projects. University of Indonesial-Press-John Hopkins, Jakarta. (in Indonesian).

6. Handayani, S. (2009). Model of Plant-Livestock Integration in Donggala District, Central Sulawesi Province: Linear Program Optimization Approach. Master's Thesis, IPB University, Bogor. (in Indonesian).

7. Indraningsih, K. S. (2015). Farmers' Perceptions of Rice Technology Innovations. https://media.neliti.com/media/publications/732-ID-persepsi-petani-terhadap-inovasiteknologi-padi.pdf. Diakses pada tanggggal 20 Juli 2017. (in Indonesian).

8. Martiningsih N. G. A. G. E., Widnyana I. K., Anom I. G. N. (2013). Transformation of Organic-Based Rice Technology in Dusun Tireman Tabanan Bali. Majalah Aplikasi Ipteks Ngayah: 4(1), Juni 2013. Universitas Mahasaraswati Denpasar, Bali. (in Indonesian).

9. Muhajir, N. (2000). Qualitative Research Methods. Fourth Edition of Rake Sarasin, Yogyakarta. (in Indonesian).

10. Mulyana, D. (2001). Methodology of Qualitative Research. PT Remaja Rosda Karya, Bandung. (in Indonesian).

11. Nam, S.S. et al (2007). Effect of irrigation level on plant growth and bulb yield during bulb development stage of garlic plants. Kor. J. Hortic. Sci. Techno.

12. Nazir. M. (1999). Methods of Social Research. Erlangga, Jakarta: Momentum. (in Indonesian).

13. Rahmi U. (2018). Analysis of Garlic (Allium Sativum L.) Farming and its Problems in Nagari Salayo Tanang Bukit Sileh, Lembang Jaya District, Solok Regency. BSc Thesis, Faculty of Agriculture, Andalas University, Padang. (in Indonesian).

14. Sadaria, S.G., Malavia, D.D., Khanpara, V.D., Dudhatra, M.G., Vyas, M.N., Mathukia, R.K. (1997). Effect of irrigation, nitrogen and phosphorus on garlic (Allium sativum) and their residual effect on groundnut (Arachis hypogaea). Indian J. Agron. 42 (4): 653-656.

15. Sánchez-Virosta, A., and Sánchez-Gómez, D. (2019). Inter-cultivar variability in the functional and biomass response of garlic (Allium sativum L.) to water availability. Scientia Horticulturae 252: 243-251.

16. Sulistyanto G. D. et al (2013). Feasibility Analysis of Rice Farming in Sebangki District, Landak Regency. Jurnal Penelitian. Universitas Tanjungpura. Pontianak. (in Indonesian).

17. Udayana I. G. B., Wirajaya A. A. N. M. (2011). Clean and Green to Bali Organic. Singhadwala $44^{\text {th }}$ edition, Denpasar, Bali. (in Indonesian).

18. Waridjo, Fallo Y. M. (2016). Garlic Farming Development Strategy in Efforts to Increase Farmers' Income in West Miomaffo District. Agrimor 1 (1): 10-12. (in Indonesian).

19. Wijaya I. P. E. (2014). Consumtion Analysis and Availability of Garlic in Indonesia. Master Thesis. Gadjah Mada University. Yogyakarta. (in Indonesian). 